\title{
Ambient measurements of biological aerosol particles near Killarney, Ireland: a comparison between real-time fluorescence and microscopy techniques
}

\author{
D. A. Healy ${ }^{1,}$, J. A. Huffman ${ }^{2,3}$, D. J. O'Connor ${ }^{1}$, C. Pöhlker ${ }^{3}$, U. Pöschl ${ }^{3}$, and J. R. Sodeau ${ }^{1}$ \\ ${ }^{1}$ University College Cork, Department of Chemistry and Environmental Research Institute, Cork, Ireland \\ ${ }^{2}$ University of Denver, Department of Chemistry and Biochemistry, Denver, Colorado, USA \\ ${ }^{3}$ Max Planck Institute for Chemistry, Multiphase Chemistry and Biogeochemistry Departments, Mainz, Germany \\ *now at: Pepsico, Global Quality Services, Cork, Ireland
}

Correspondence to: D. A. Healy (d.healy@ucc.ie) and J. A. Huffman (alex.huffman@ du.edu)

Received: 19 January 2014 - Published in Atmos. Chem. Phys. Discuss.: 11 February 2014

Revised: 27 June 2014 - Accepted: 30 June 2014 - Published: 13 August 2014

\begin{abstract}
Primary biological aerosol particles (PBAPs) can contribute significantly to the coarse particle burden in many environments. PBAPs can thus influence climate and precipitation systems as cloud nuclei and can spread disease to humans, animals, and plants. Measurement data and techniques for PBAPs in natural environments at high time- and size resolution are, however, sparse, and so large uncertainties remain in the role that biological particles play in the Earth system. In this study two commercial real-time fluorescence particle sensors and a Sporewatch single-stage particle impactor were operated continuously from 2 August to 2 September 2010 at a rural sampling location in Killarney National Park in southwestern Ireland. A cascade impactor was operated periodically to collect size-resolved particles during exemplary periods. Here we report the first ambient comparison of a waveband integrated bioaerosol sensor (WIBS-4) with a ultraviolet aerodynamic particle sizer (UV-APS) and also compare these real-time fluorescence techniques with results of fluorescence and optical microscopy of impacted samples. Both real-time instruments showed qualitatively similar behavior, with increased fluorescent bioparticle concentrations at night, when relative humidity was highest and temperature was lowest.

The fluorescent particle number from the FL3 channel of the WIBS-4 and from the UV-APS were strongly correlated and dominated by a $3 \mu \mathrm{m}$ mode in the particle size distribution. The WIBS FL2 channel exhibited particle modes at approx. 1 and $3 \mu \mathrm{m}$, and each was correlated with the concen-
\end{abstract}

tration of fungal spores commonly observed in air samples collected at the site (ascospores, basidiospores, Ganoderma spp.). The WIBS FL1 channel exhibited variable multimodal distributions turning into a broad featureless single mode after averaging, and exhibited poor correlation with fungal spore concentrations, which may be due to the detection of bacterial and non-biological fluorescent particles. Cladosporium spp., which are among the most abundant fungal spores in many terrestrial environments, were not correlated with any of the real-time fluorescence channels, suggesting that the real-time fluorescence instruments are relatively insensitive to PBAP classes with dark, highly absorptive cell walls.

Fluorescence microscopy images of cascade impactor plates showed large numbers of coarse-mode particles consistent with the morphology and weak fluorescence expected of sea salt. Some of these particles were attached to biological cells, suggesting that a marine source influenced the PBAPs observed at the site and that the ocean may be an important contributor to PBAP loadings in coastal environments.

\section{Introduction}

The in situ monitoring of primary biological aerosol particles (PBAPs) with high time resolution represents an important technological development made capable, in part, by long-standing, military-led research into the detection of 
biological warfare agents. The more recent drive to monitor ambient, atmospheric PBAPs is largely related to adverse effects they play in human and agricultural health (allergic rhinitis, food crop damage) (Lacey and Dutkiewicz, 1994; Patel and Bush, 2000; Pöschl, 2005; Shiraiwa et al., 2012). Several classes of bioaerosols have been shown to act as cloud and ice nuclei in laboratory settings (e.g., Maki et al., 1974; Diehl et al., 2001; Morris et al., 2004, 2013; Möhler et al., 2007; Pummer et al., 2012; Haga et al., 2013), and ambient measurements have shown PBAPs to be ubiquitously associated with rain and snowfall as well as present in clouds (Christner et al., 2008; Pöschl et al., 2010; DeLeonRodriguez et al., 2013; Huffman et al., 2013; Prenni et al., 2013). Thus, it has been suggested that PBAPs may impact precipitation and the hydrological cycle, and may ultimately affect the weather and climate of a region (Sands et al., 1982; Morris et al., 2008, 2014). A review of biological aerosol properties and detection methods is beyond the scope of this text, but comprehensive PBAP overviews are available (e.g., Madelin, 1994; Ho, 2002; Fröhlich-Nowoisky et al., 2009; Womack et al., 2010; Caruana, 2011; Xu et al., 2011; Després et al., 2012; Fröhlich-Nowoisky et al., 2012).

Common usage of the term PBAP includes various classes of biological particles, including viruses; bacteria; fungal, moss, and fern spores; pollen; algal and plant cells; and insects, mites, and their fragments including excreta (Després et al., 2012). Such PBAPs have been well studied within the aerobiology community for many decades using traditional methods of impact collection followed by microscopic counting and identification procedures. These analyses can be time consuming and require significant processing cost and skill. In contrast, relatively few studies have reported ambient collection and analysis of bioaerosols at high time resolution (e.g., seconds to minutes), due to the lack of instrumentation capable of monitoring particles on such fast timescales. Recent studies utilizing real-time PBAP measurements have collected and analyzed ambient PBAP data for periods as long as 18 consecutive months (Pan et al., 2007; Huffman et al., 2010; Gabey et al., 2011; Schumacher et al., 2013; Toprak and Schnaiter, 2013). Such measurements obtained with high time resolution can subsequently aid our understanding of atmospheric PBAP properties including sub-diurnal boundary layer transport and cloud formation. Recently, work to model bioaerosol emissions on global and regional scales has attempted to quantify the impact that PBAPs have on coarse aerosol loadings and ice nuclei properties (e.g., Burrows et al., 2009a, b; Heald and Spracklen, 2009; Hoose et al., 2010; Sesartic et al., 2013; Hummel et al., 2014); however, more detailed understanding of PBAP inputs is necessary to constrain model results.

A number of optical systems utilizing light/laser-induced fluorescence (LIF) have been developed to detect airborne biological material based on the presence of biological fluorophores in the particle. Instrumentation available for military research use, but not commercial/civilian use, include aerosol fluorescence spectrum analyzers (AFSA) (Pinnick et al., 1995, 2004; Pan et al., 2011) and single-particle fluorescence analyzers (SPFA) (Eversole et al., 1999; Sivaprakasam et al., 2011). Within approximately the last decade, commercially available devices have become obtainable for purchase and use by non-military communities. Similar to approaches developed in military-based laboratories, these commercial instruments provide real-time (on-line) detection of biological particles suspended in the air. Two single-particle fluorescence instruments that have been used most widely within the atmospheric aerosol research community include the ultraviolet aerodynamic particle sizer (UV-APS; TSI Inc. model 3314, St. Paul, MN) (Hairston et al., 1997; Brosseau et al., 2000; Huffman et al., 2010) and the waveband integrated bioaerosol sensor (WIBS; originally developed by the University of Hertfordshire, UK, and now licensed and sold by Droplet Measurement Technology, Boulder, CO) (Kaye et al., 2005; Foot et al., 2008; Stanley et al., 2011). Fluorescent emission excited by $\sim 360 \mathrm{~nm}$ radiation is considered to include the presence of metabolites (e.g., $\mathrm{NAD}(\mathrm{P}) \mathrm{H}$, riboflavin) within living cells. Emission related to excitation by $\sim 280 \mathrm{~nm}$ radiation is usually attributed to proteins and amino acids present in all biological material, whether living or dead (Pöhlker et al., 2012, 2013). However, observed fluorescence signals at a given wavelength are likely to arise from a complex mixture of bio-fluorophores in the particle (Pöhlker et al., 2012).

A growing body of published reports suggest that particle autofluorescence can be used, to a first approximation, to separately detect biological and non-biological particles (Huffman et al., 2012; Pöhlker et al., 2012; Robinson et al., 2013). However, secondary organic aerosol (SOA), humic-like substance (HULIS), and other atmospheric materials have been suggested to interfere with detection of ambient biological particles via fluorescence (e.g., Huffman et al., 2010; Pöhlker et al., 2012; Gabey et al., 2013; Lee et al., 2013). In contrast, no real-time technique for PBAP analysis is able to comprehensively detect all classes of biological material. Microorganisms too large or too small for efficient collection by UV-LIF instrument will undercount these particles, and some PBAPs may fluoresce too weakly to be detected in many circumstances. Despite these physical uncertainties, measurements in the remote Amazon Basin of Brazil showed that fluorescent particle number closely approximated biological particles measured by electron microscopy (Huffman et al., 2012), suggesting that techniques utilizing particle autofluorescence can be used in some geographic environments as first-approximation classifiers between biological and nonbiological particles and can provide a lower limit for the atmospheric abundance of PBAPs in the super-micron (>1 $\mu \mathrm{m})$ size range. More work is needed to better understand the scenarios in which this assumption holds.

This study represents the first colocated ambient deployment of the UV-APS and WIBS-4 instruments. Results suggest a good qualitative comparison between the two real-time 
techniques as well as with optical microscopy measurements performed on samples simultaneously collected via impaction. The comparisons reported here help characterize real-time fluorescence instrument capabilities for atmospheric bioaerosol measurement and will improve the ability of the atmospheric research community to reliably detect PBAPs.

\section{Methodology}

\subsection{Location of sampling site}

Sampling was performed between 2 August and 2 September 2010 within Killarney National Park (KNP), Kerry, which is situated in southwest Ireland $\left(52^{\circ} 01.263^{\prime} \mathrm{N}, 09^{\circ} 30.553^{\prime} \mathrm{W}\right)$. The site was located on the eastern perimeter of Reenadinna Woods, in a small clearing $(\sim 30 \mathrm{~m} \times 50 \mathrm{~m})$ of manicured grass surrounded by Taxus baccata, yew trees, and within meters of Muckross Lake (Fig. S1 in the Supplement). KNP is one of the westernmost European national parks. The site can be characterized as clean and rural, with local southwesterly winds and incoming air masses influenced most heavily from pristine Atlantic trajectories, including minimal influence from anthropogenic emissions. The site comprises mixed deciduous trees and rich undergrowth. A list of typical botanic species found in Reenadinna Woods is outlined elsewhere (Kelly, 1981).

All instruments were housed in a purpose-built mobile laboratory trailer ( $3 \mathrm{~m}$ length), which was positioned immediately adjacent to a lawn area in front $(\sim 5 \mathrm{~m})$ of the unoccupied Arthur Vincent House, from where electrical power was obtained. Sample inlets extended vertically from the mobile laboratory were approximately $2.5-3.0 \mathrm{~m}$ in height above ground level and positioned approximately $4 \mathrm{~m}$ from the nearest trees.

\subsection{Instrumentation}

\subsubsection{WIBS}

The waveband integrated bioaerosol sensor model 4 (WIBS4) used here was a prototype of a series of real-time biological particle sensors developed by the University of Hertfordshire in the United Kingdom (Kaye et al., 2005; Foot et al., 2008; Gabey et al., 2011; Stanley et al., 2011; Healy et al., 2012a, b). Briefly, the WIBS-4 consists of a central optical chamber, around which are arranged (i) a continuous-wave $635 \mathrm{~nm}$ diode laser used for the initial detection of particles and the determination of particle size (optical diameter), (ii) a forward light-scattering quadrant photomultiplier used in the determination of particle size and asymmetry, and (iii) two pulsed xenon flashtube UV sources emitting sequentially at 280 and $370 \mathrm{~nm}$. Fluorescence emission is detected in two bands: $310-400 \mathrm{~nm}$ (band 1) and $420-650 \mathrm{~nm}$ (band 2). Thus, for each particle, three fluorescence measurements are pro- vided: (i) excitation at $280 \mathrm{~nm}$, emission in band 1 (FL1); (ii) excitation at $280 \mathrm{~nm}$, emission in band 2 (FL2); and (iii) excitation at $370 \mathrm{~nm}$, emission in band 2 (FL3). For each individual particle detected, the instrument also provides the optical particle size $\left(D_{\mathrm{o}}\right)$ and the particle asymmetry factor $\left(A_{\mathrm{f}}\right)$, which is a parameter that describes the degree of symmetry for the forward-scattered light (Kaye et al., 2005). Light detected by a four-quadrant photomultiplier tube (PMT) is combined to calculate an $A_{\mathrm{f}}$; a spherical particle has $A_{\mathrm{f}}$ of 0 , and rod-shaped fibers yields $A_{\mathrm{f}}$ near 100 (Gabey et al., 2010).

The particle counting efficiency of the WIBS-4 used in the current study drops below unity at $D_{\mathrm{o}}<0.69 \mu \mathrm{m}$ with $D_{50}$ at $0.49 \mu \mathrm{m}$ (Healy et al., 2012b). Therefore, number concentrations for particles with $D_{\mathrm{o}}<0.69 \mu \mathrm{m}$ should be considered as lower-limit values. The upper size limit is defined as a function of the PMT gain setting and was approx. $13 \mu \mathrm{m}$ for this study. It is possible to operate the Hertfordshire WIBS4 instruments at a different gain setting for the detection of particles up to approximately $31 \mu \mathrm{m}$ in diameter. However, the configuration utilized here only permits optical particle sizing of particles between approx. 0.5 and $13 \mu \mathrm{m}$.

The trigger threshold setting of WIBS-4 (Trig) is an instrumental parameter that can be adjusted to predefine the lower particle size limit for which the firing of the xenon UV flash lamps (i.e., fluorescence excitation) will be triggered. The effects of such adjustments, i.e., minimum particle size as a function of Trig setting, had not previously been explored in an ambient setting. Furthermore WIBS instruments manufactured by the University of Hertfordshire are each unique prototypes and therefore the operational settings are not necessarily comparable between instruments. Three Trig settings were used for the WIBS-4 during the campaign (see also Sect. 3.2). A Trig setting of 8 (2-5 August) corresponded to minimum detectable particle size of $0.52 \mu \mathrm{m}$ (channel $\geq 1$; see Supplement Table S1). A Trig setting of 20 (5-18 and 27-31 August) corresponded to a minimum particle size of $0.65 \mu \mathrm{m}$ (channel $\geq 4$ ). Lastly, a Trig setting of 30 (23-27 August and 31 August-2 September) corresponded to a minimum particle size of $0.75 \mu \mathrm{m}$ (channel $\geq 6$ ).

The performance of the two xenon flashtubes within the WIBS-4 was monitored throughout the measurement period. Flashtube power output values were recorded; upperand lower-limit values were determined as $\pm 3 \sigma$ (as standard deviation) from the mean. All particles resulting from UV flashes with power outside these bounds were eliminated from the fluorescent particle number concentration calculations. Note, however, that the total particle concentrations remained unaffected.

\subsubsection{UV-APS}

An ultraviolet aerodynamic particle sizer was utilized and operated using standard procedures (e.g., Huffman et al., 2010) and thereby provided $5 \mathrm{~min}$ ensemble averages of number concentration, fluorescence intensity, and size of 
particles (Hairston et al., 1997; Brosseau et al., 2000). Aerodynamic particle sizing $\left(D_{\mathrm{a}}\right)$ in the diameter range between 0.5 and $20 \mu \mathrm{m}$ is obtained by measuring time of particle flight between two red $(633 \mathrm{~nm}) \mathrm{He}-\mathrm{Ne}$ interrogating lasers. Optical excitation of the individual particles is provided by a pulsed Nd:YAG laser operating at $355 \mathrm{~nm}$. Subsequent fluorescence is collected in a single bin (not wavelength dispersed) within the wavelength range between 420 and $575 \mathrm{~nm}$. UV-APS particle transmission drops below unity at approximately $0.8 \mu \mathrm{m}$, with $D_{50}$ estimated at approx. $0.5 \mu \mathrm{m}$ (Huffman et al., 2012), and thus particles smaller than approximately $1 \mu \mathrm{m}$ are conservatively treated as lower-limit values.

\subsubsection{Real-time fluorescence instrument comparison}

Both WIBS-4 and UV-APS instruments sampled ambient air from the same inlet as shown in Fig. S2 in the Supplement. The vertical inlet line consisted of $0.5 \mathrm{in}$. stainless steel tube and was connected to a $0.5 \mathrm{in}$. Y splitter with Swagelok fittings. Connections to both instruments after the split were made using conductive rubber tubing with an internal diameter of approx. 0.75 in. (Simolex Rubber Corp., Plymouth, MI). A bypass flow of $2.4 \mathrm{~L} \mathrm{~min}^{-1}$ was drawn through a Swagelok tee (at $90^{\circ}$ ) from the WIBS-4 line to match flows at $4.8 \mathrm{~L} \mathrm{~min}^{-1}$ on either branch of the $\mathrm{Y}$ junction. Flow rates were regularly checked throughout the sample line with an external flowmeter (TSI Inc. model 4140 thermal mass flowmeter). The instruments and auxiliary pump pulled a total flow of $9.6 \mathrm{~L} \mathrm{~min}^{-1}$ through the inlet.

The WIBS-4 records the size of each individual particle sampled, but particles were binned according to UV-APS particle size channels for ease of comparison. Integrated particle number concentrations for each instrument are given for the size range greater than $1 \mu \mathrm{m}$ in all cases here. A summary of the characteristic features and settings used by both WIBS-4 and UV-APS as operated here is outlined in Table 1.

The detection limit for each fluorescence channel of the WIBS- 4 is defined as the mean $+3 \sigma$ fluorescence signal detected during $>10 \mathrm{~min}$ of Xe lamp flashes (forced trigger data acquisition mode) with no particle flow (i.e., pump off) (Gabey et al., 2010). Hence for each fluorescence channel (FL1, FL2, and FL3) the measured detection limit is taken as the minimum fluorescence intensity that can be reliably obtained from an individual particle by WIBS-4. In contrast, the UV-APS bins the fluorescence intensity of individual particles into 1 of 64 channels, with no attempt to measure fundamental detection limit on a per-particle basis. Particles with no measured fluorescence signal appear in channel 1. For the current study, particles that give fluorescence signals in channels $>3$ were defined as FBAP (Huffman et al., 2010).

WIBS-4 PMT voltage values were $0.701 \mathrm{~V}$ for FL1 and $0.649 \mathrm{~V}$ for both FL2 and FL3. The UV-APS PMT voltage was set $380 \mathrm{~V}$ as set by the factory to exclude polystyrene latex spheres (PSL) from being characterized as fluorescent.
Increasing the UV-APS PMT setting allows for more sensitive detection of particle fluorescence signal, but also increases the noise and likelihood of weakly fluorescent nonbiological particles being counted as FBAP.

\subsubsection{Sporewatch particle impactor}

The Burkard Sporewatch sampler (Burkard Scientific, UK) is a volumetric Hirst-type particle trap that operates by drawing air in through an orifice at a constant rate $\left(10 \mathrm{~L} \mathrm{~min}^{-1}\right)$, allowing particles to impact onto silicone-coated tape (Lanzoni) mounted on a rotating drum (Hirst, 1952). The sampler was mounted on the roof of the mobile laboratory trailer (sampling height $\sim 3 \mathrm{~m}$ above ground) and operated to rotate at a rate of one revolution per week, with start and end times manually recorded. Tapes were changed weekly, stored in air-sealed bags at $\sim 4^{\circ} \mathrm{C}$, and then cut into seven daily segments for analysis. Tape segments were mounted on microscope slides and counts of the identifiable fungal spores and pollen species were recorded. Microscope slides were stained with fuchsine (Sigma Aldrich) and the samples were examined under $400 \times$ magnification using an optical light microscope (VWR, TR500) according to regulations of the British Aerobiology Federation (Lacey and Venette, 1995). A longitudinal counting method was used, meaning that microscopic observation was performed in one continuous sweep through the center of the $24 \mathrm{~h}$ tape. Only $3 \%$ of the total tape area is observed at a given time by this method and particle concentrations are scaled accordingly. A more detailed description of the method is described elsewhere (Sterling et al., 1999; Lacey and West, 2007). Count values were converted into atmospheric number concentrations by scaling to the full tape width and dividing by the volumetric flow rate of the sampler after assuming that particles were deposited onto the tape with unit efficiency. Resultant concentrations are listed as counts per cubic centimeter of air $\left(\mathrm{cm}^{-3}\right)$.

Particle counting by this technique is done manually, and so several biases are possible. First, both the sensitivity and selectivity of the characterization is user dependent. In this case, fungal spores and pollen grains were investigated and counted. Particles smaller than approximately $2 \mu \mathrm{m}$ were not counted. Individual bacteria or small bacterial agglomerates, for example, would thus not have been counted by this method. Further, many fungal spores are hyaline (translucent, glassy appearance when examined by microscope) in nature and are therefore difficult to enumerate via optical microscopy. Lastly, the collection efficiency of the Sporewatch impactor drops below unity for particles smaller than approximately 3-5 $\mu \mathrm{m}$ (Khattab and Levetin, 2008). For these reasons, particle concentration values reported here should be taken as lower-limit values. 
Table 1. A comparison between instrumental parameters used during the study for the UV-APS and WIBS-4 techniques.

\begin{tabular}{|c|c|c|}
\hline & $\begin{array}{l}\text { UV-APS } \\
\text { (TSI model no. } 3314 \text { ) }\end{array}$ & $\begin{array}{l}\text { WIBS } \\
\text { (Univ. Hertfordshire model no. } 4 \text { ) }\end{array}$ \\
\hline $\begin{array}{l}\text { Summary of measure- } \\
\text { ment capabilities }\end{array}$ & $\begin{array}{l}\text { particle size, intrinsic particle fluores- } \\
\text { cence ( } 1 \text { channel), particle side-scatter } \\
\text { light intensity }\end{array}$ & $\begin{array}{l}\text { particle size, intrinsic particle fluorescence ( } 3 \text { chan- } \\
\text { nels), particle asymmetry }\end{array}$ \\
\hline Aerosol sample flow rate & $1.0 \mathrm{~L} \mathrm{~min}^{-1}$ & $0.23 \mathrm{~L} \mathrm{~min}^{-1}$ \\
\hline Sampling time & $\begin{array}{l}\text { user-defined binning } \\
\text { ( } 5 \text { min here) }\end{array}$ & $\begin{array}{l}\text { individual particle detection } \\
\text { (post-binned to } 5 \mathrm{~min} \text { ) }\end{array}$ \\
\hline Sizing method & aerodynamic diameter $\left(D_{\mathrm{a}}\right)$ & optical diameter $\left(D_{\mathrm{o}}\right)$ \\
\hline Size resolution & $\begin{array}{l}52 \text { channels selected via acquisition } \\
\text { software }\end{array}$ & $\begin{array}{l}52 \text { channels post-binned to match UV-APS ( } 45 \\
\text { channels utilized due to } \max D_{\mathrm{o}} \sim 13 \mu \mathrm{m} \text { ) }\end{array}$ \\
\hline Particle size range & $D_{\mathrm{a}}: \sim 0.5$ to $\sim 20 \mu \mathrm{m}$ & $D_{\mathrm{o}}: \sim 0.5 \mu \mathrm{m}$ to $\sim 13 \mu \mathrm{m}$ \\
\hline Excitation source & $355 \mathrm{~nm}$ via UV laser (Nd:YAG) & $\begin{array}{l}280 \text { and } 370 \mathrm{~nm} \text { via } \\
\text { xenon flashtubes with blocking filters }\end{array}$ \\
\hline Fluorescence & $\begin{array}{l}\lambda_{\mathrm{ex}}=355 \mathrm{~nm} \\
\lambda_{\mathrm{em}}=420-580 \mathrm{~nm}\end{array}$ & $\begin{array}{l}\text { FL1 } \lambda_{\mathrm{ex}}=280 \mathrm{~nm} \\
\lambda_{\mathrm{em}}=310-400 \mathrm{~nm} \\
\text { FL2 } \lambda_{\mathrm{ex}}=280 \mathrm{~nm} \\
\lambda_{\mathrm{em}}=420-650 \mathrm{~nm} \\
\text { FL3 } \lambda_{\mathrm{ex}}=370 \mathrm{~nm} \\
\lambda_{\mathrm{em}}=420-650 \mathrm{~nm}\end{array}$ \\
\hline Particle asymmetry & $\mathrm{n} / \mathrm{a}$ & $\begin{array}{l}A_{\mathrm{F}} \text { via side-scatter intensity in four quadrants } \\
\left(A_{\mathrm{F}}=0 \text {, sphere; } A_{\mathrm{F}} \gg 0 \text {, high aspect ratio fiber }\right)\end{array}$ \\
\hline
\end{tabular}

\subsubsection{MOUDI particle impactor}

Size-resolved particle samples were collected using a microorifice uniform deposition impactor (MOUDI; MSP, model 110) at a flow rate of $30 \mathrm{~L} \mathrm{~min}^{-1}$ via a dedicated inlet. Cut points of aerosol size fractionation have been discussed elsewhere (Marple et al., 1991). Samples were collected onto glass microscope slides for subsequent analysis via fluorescence microscopy.

\subsubsection{Fluorescence microscopy}

Fluorescence microscopy images were taken using a BZ9000 fluorescence microscope (Keyence Inc., Osaka, Japan). The instrument was equipped with a super-high-compression mercury lamp $(120 \mathrm{~W})$ and a $2 / 3$ in., 1.5-megapixel monochrome charge-coupled device. The following fluorescence filters were used to take images in different spectral ranges: OP-66834 DAPI-BP $\left(\lambda_{\mathrm{ex}}=360 / 20 \mathrm{~nm}, \lambda_{\text {Dichroic }}=\right.$ $\left.400 \mathrm{~nm}, \lambda_{\text {Absorp }}=460 / 25 \mathrm{~nm}\right)$, OP-66836 GFP-BP $\left(\lambda_{\text {ex }}=\right.$ $\left.470 / 20 \mathrm{~nm}, \lambda_{\text {Dichroic }}=495 \mathrm{~nm}, \lambda_{\text {Absorp }}=535 / 25 \mathrm{~nm}\right)$, OP66838 TexasRed $\left(\lambda_{\mathrm{ex}}=560 / 20 \mathrm{~nm}, \lambda_{\text {Dichroic }}=595 \mathrm{~nm}\right.$, $\left.\lambda_{\text {Absorp }}=630 / 30 \mathrm{~nm}\right)$. Filter specifications are represented as wavelength and peak width $(\lambda / \mathrm{FWHM})$.

\subsubsection{Meteorological data}

Wind speed, wind direction, temperature, humidity, downwelling solar radiation, and rainfall were monitored using a Casella NOMAD weather station mounted on the roof of the
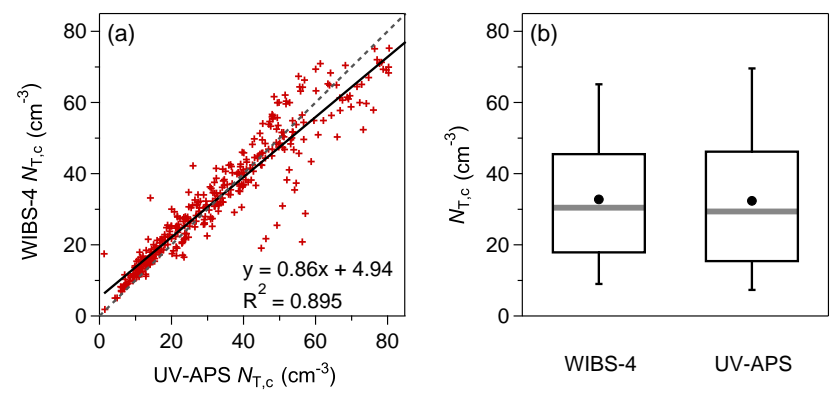

Figure 1. Comparison of concentrations of total coarse particles $(D>1 \mu \mathrm{m})$ over the entire $\sim 1$ month measurement period. Red symbols (a) show 5 min data points, and the solid black line shows linear fit (not weighted). Dashed line is $1: 1$ line. Statistical summary of $N_{\mathrm{T}, \mathrm{c}}$ shown as box-and-whisker plots (b). Black dots show the mean, the horizontal gray bar shows the median, boxes show the 25-75th percentile, and vertical bars show the 5-9th percentile.

mobile laboratory trailer. Measurements were made at $5 \mathrm{~min}$ intervals.

\section{Results and discussion}

\subsection{Total particle comparison}

The WIBS-4 and UV-APS instruments were operated continuously behind the same inlet for approximately 1 month. Mean coarse particle number concentration $\left(N_{\mathrm{T}, \mathrm{c}}\right.$, $D>1 \mu \mathrm{m}$ ) was 32.8 and $32.4 \mathrm{~cm}^{-3}$ for WIBS-4 and UV-APS, 


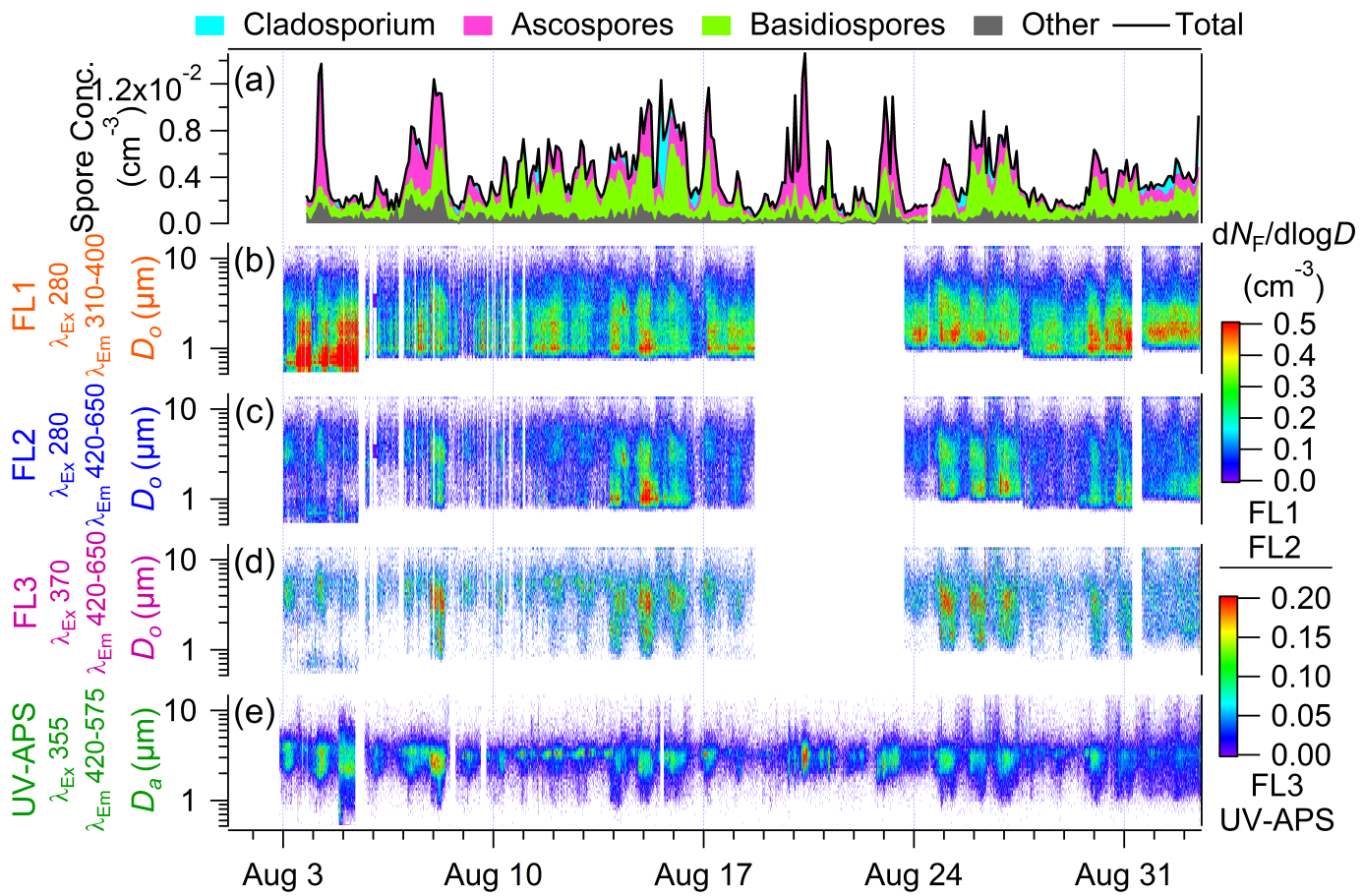

Figure 2. Campaign overview time series. Selected biological particles identified by Sporewatch technique (a). Size-resolved measurements of fluorescent particles as determined by WIBS FL1 (b), FL2 (c), and FL3 (d) channels, and UV-APS (e). Color scale for image plots (b-e) shown as $\mathrm{d} N_{\mathrm{F}} / \mathrm{d} \log D\left(\mathrm{~cm}^{-3}\right)$ on the right and is separated into FL1, FL2 (upper scale) and FL3, UVAPS (lower scale). Data reported for both WIBS-4 and UV-APS as $5 \mathrm{~min}$ averages and for Sporewatch as $2 \mathrm{~h}$ averages.

respectively (Fig. 1), suggesting that there were no significant differences in sampling losses between the two branches of the inlet flow. Figure 1 also shows the correlation of total particle concentration between the instruments, averaged into $5 \mathrm{~min}$ samples. The quantitative comparison between the instruments is good, with an $R^{2}$ value of 0.90 over the campaign. The slope of 0.86 , however, suggests that the WIBS method undercounted the total particle concentrations with respect to the UV-APS, especially at concentrations above approx. $50 \mathrm{~cm}^{-3}$. The shallow slope to the correlation above $50 \mathrm{~cm}^{-3}$ is likely a result of particle coincidence that reduced particle counts within the WIBS at a lower concentration than within the UV-APS due to differing physical instrument parameters. Size-resolved total particle concentrations measured throughout the campaign by both instruments are shown in Fig. S3 in the Supplement.

\subsection{Overview of fluorescent aerosol trends}

A comprehensive overview of biological particle measurements from Sporewatch/optical microscopy, WIBS-4, and UV-APS methods as employed over the whole measurement period is shown in Fig. 2. A coarse view of the measurements shows broad agreement between the techniques, with rhythmic, synchronous increases in particle number across platform and wavelength channel in addition to episodic events of high concentration. Step functions in the lower size of flu- orescent particles from the FL1 channel (Fig. 2b) highlight periods when different trigger values were used to investigate optimal WIBS-4 operation (Sect. 2.2.1). Ignoring the corresponding minor fluctuation in lower particle size, as shown by the size-resolved image plots (Fig. 2), the same pattern through time emerges.

The WIBS FL1 channel typically shows a broad, multimodal distribution (Fig. 3), with three distinct modes present for most of 5-18 August, and a bimodal distribution present for most of the rest of the campaign. The presence of the smallest mode (approx. $1.0 \mu \mathrm{m}$ ) during the period when the trigger value was set the lowest highlights the influence that this WIBS setting has on the detection of particles and the relative shape of fluorescent particle size distributions at small sizes. While discreet modes are present in the timeresolved size distributions (Fig. 2), these fine temporal differences are largely smoothed away when looking at average size distributions over the entire measurement period (Fig. 3a). The WIBS FL2 channel also shows a bimodal distribution, with consistent peaks at approx. 1 and $3 \mu \mathrm{m}$ in particle size (Figs. 2c and 3b).

The size distributions from the WIBS FL3 channel and UV-APS, in contrast to WIBS FL1 and FL2 channels, show much stronger signal at the $3 \mu \mathrm{m}$ particle size and relatively minimal influence from the $1 \mu \mathrm{m}$ mode. The qualitative correlation in particle size between WIBS FL3 and 

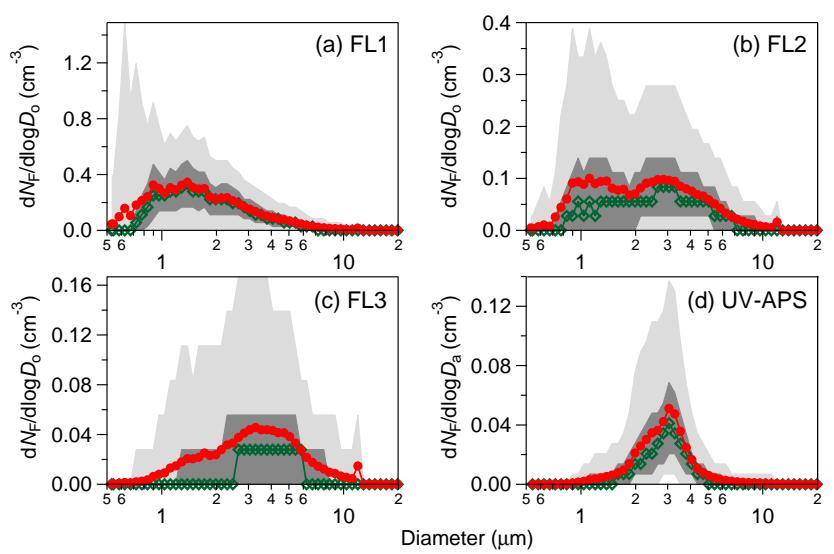

Figure 3. Average FBAP number size distributions measured by WIBS-4 for (a) FL1, (b) FL2, (c) FL3, and (d) UV-APS for the entire sampling period. Red traces show mean values, green traces show median, dark-gray areas show $25-75$ th percentile, and lightgray areas show 5-95th percentiles. Vertical scale is different in each panel.

UV-APS signals is expected, because the excitation wavelengths (370 and $355 \mathrm{~nm}$, respectively) are both designed to highlight molecules related to active cellular metabolism (e.g., NAD(P)H and riboflavin) (Harrison and Chance, 1970; Setlow and Setlow, 1977; Eng et al., 1989; Li et al., 1991). There is no doubt that the assumption that detecting fluorescence from these channels implies the presence of actively metabolizing cells significantly over-simplifies the perspective of airborne microorganisms (Pöhlker et al., 2012, 2013). The broad nature of fluorescence excitation and emission spectra along with the relative similarity of excitation wavelength between these channels of the two instruments leads to broad consistency between the WIBS FL3 and UV-APS trends. However, despite the relative agreement between the peaks and temporal patterns of WIBS FL3 and UV-APS, Fig. $3 c$ and d show significantly reduced presence of the $1.2 \mu \mathrm{m}$ mode in UV-APS compared to the WIBS FL3. This suggests that the UV-APS was less sensitive to smaller fluorescent particles, and thus may not record particles $<2 \mu \mathrm{m}$ as efficiently as the WIBS-4. The influence of particle size on fluorescent particle detection is likely a result of the fact that fluorescence detected from individual particles scales as a function of the second to third power of particle diameter, depending on the depth of excitation photon penetration into the interrogated particle (Tanke et al., 1982; Hill et al., 2001; Sivaprakasam et al., 2004). Further, the UV-APS is typically operated with relatively poor sensitivity in order to reduce the possible inclusion of non-biological artifacts in the fluorescence measurement (Huffman et al., 2012).

Both FL1 and FL2 channels are a result of excitation at $280 \mathrm{~nm}$, which can probe proteins, amino acids, and other bio-fluorophores. The differences between FL1 $\left(\lambda_{\mathrm{em}} 310\right.$ $400 \mathrm{~nm})$ and FL2 $\left(\lambda_{\mathrm{em}} 420-650 \mathrm{~nm}\right)$ channels, however,
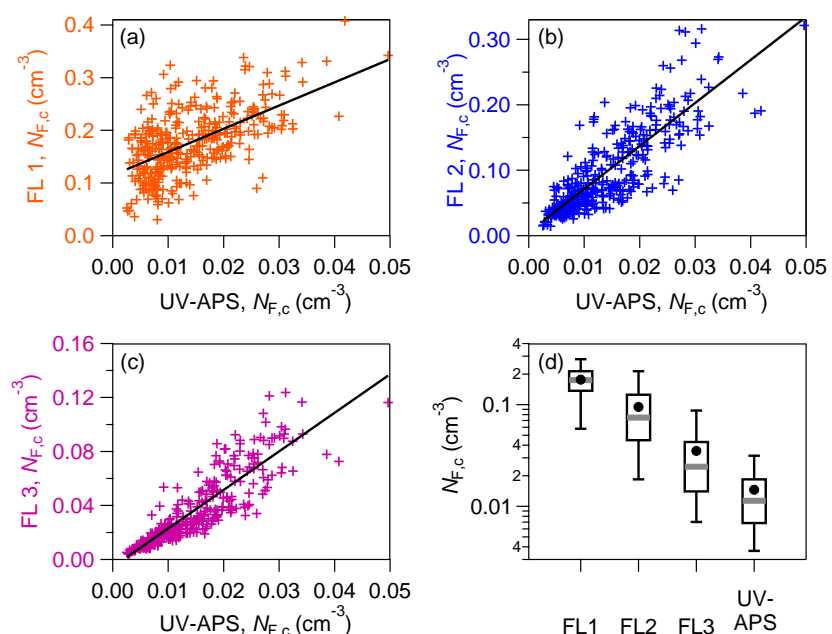

Figure 4. Comparison of coarse $(>1 \mu \mathrm{m})$ fluorescent particle number $\left(N_{\mathrm{F}, \mathrm{c}}\right)$ between individual WIBS channels and UV-APS shown for entire measurement period. Colored crosses show individual 5 min data $(\mathbf{a}-\mathbf{c})$, and black diagonal lines show unweighted linear fits. Correlation coefficients are FL1, $R^{2} 0.34$ (a); FL2, $R^{2} 0.68$ (b); and FL3, $R^{2} 0.78$ (c). Statistical overview of all data shown for each channel as box-and-whisker plots (d), where the black dot is the mean, horizontal gray bar the median, black box the 25-75th percentile, and vertical bars the 5-95th percentiles. Vertical scales are different in each correlation plot $(\mathbf{a}-\mathbf{c})$.

can highlight different molecules. For example, Pöhlker et al. (2012) show that the FL1 band is much more efficient at detecting certain amino acids and proteins, whereas the FL2 channel detects flavin compounds (naturally occurring pigments, including riboflavin) at higher efficiency. This may also explain the qualitative overlap between the FL2 channel with aspects of each of the FL1 and FL3 channels, while the FL1 and FL3 channels show relatively little similarity in size distribution.

A quantitative comparison between the fluorescence channels detected is provided in Fig. 4, with each WIBS channel shown with respect to UV-APS fluorescent particle number. As discussed, of all WIBS channels, FL3 $N_{\mathrm{F}, \mathrm{c}}$ displays the highest correlation with UV-APS $N_{\mathrm{F}, \mathrm{c}}\left(R^{2} 0.78\right)$. The correlation between FL2 and UV-APS was also quite high $\left(R^{2} 0.68\right)$, but between FL1 and UV-APS the correlation was poor $\left(R^{2} 0.34\right)$. As mentioned, the good correlation between FL3 and UV-APS is expected because of the common excitation and emission wavelengths employed by the two measurements. However, the UV-APS undercounts the FL3 measurement by a factor of 2.7 (Fig. 4d). In contrast, the WIBS FL1 and FL2 signals result from fundamentally different fluorophores that result in much higher number concentrations.

Results of the Sporewatch analysis show qualitative agreement with temporal cycles from the single-particle fluorescence measurements (Figs. 2, 5); when each of the real-time fluorescence channels peak, a corresponding peak in spore 


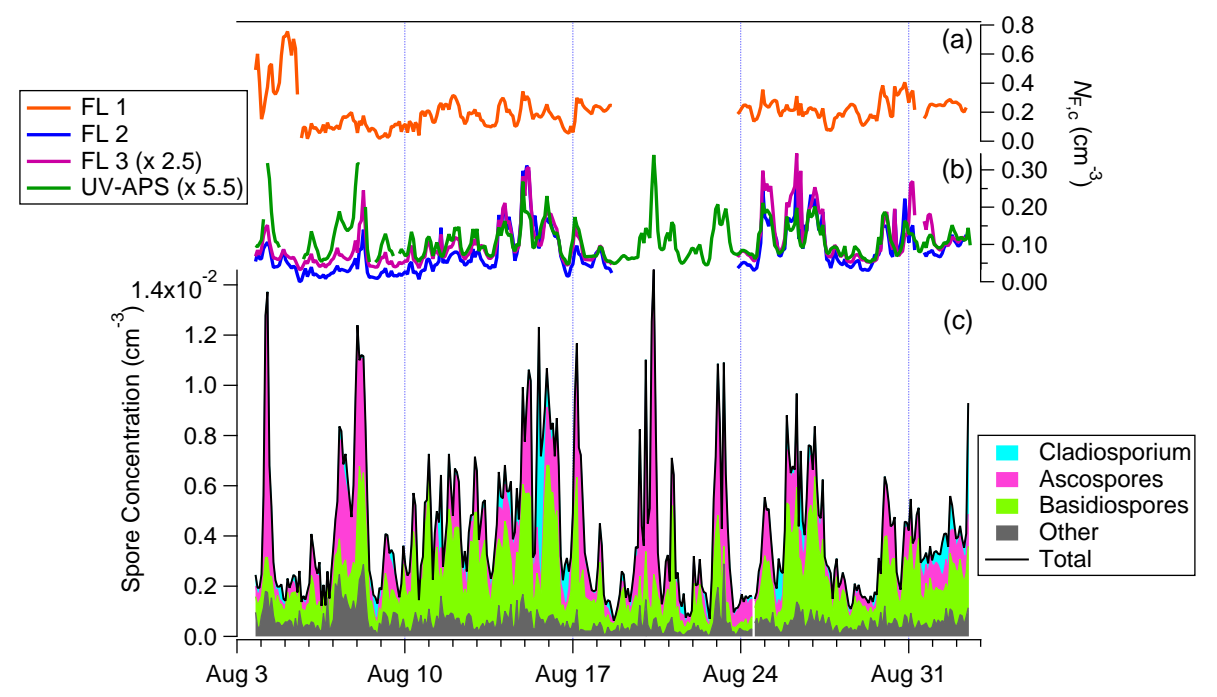

Figure 5. Temporal trends observed for coarse fluorescent particles (a-b) and spores sampled by Sporewatch (c). WIBS FL1 $N_{\mathrm{F}, \mathrm{c}}$ plotted alone (a); WIBS FL2, FL3, and UV-APS $N_{\mathrm{F}, \mathrm{c}}$ traces plotted together (b). Scaler values applied to FL3 and UV-APS traces are shown in the legend.

concentrations can be seen as well. Correlation analysis discussed later highlights the agreement further (Fig. 6). A comparison of the diurnal cycles will be discussed in Sect. 3.3. It is of note that the differing time resolution of the techniques used $(5 \mathrm{~min}$ for real-time fluorescence instruments, $2 \mathrm{~h}$ for Sporewatch) results in small temporal shifts in peaks of number concentrations.

\subsection{Real-time fluorescence sensors vs. Sporewatch}

The advantage of the Sporewatch technique paired with optical microscopy is that number concentrations of individual microorganism types can be directly measured as a function of time. The most commonly observed species $(2-10 \mu \mathrm{m})$ at the KNP site during this experiment were all fungal spores: Cladosporium spp., Ganoderma spp., basidiospores, and ascospores. Ascospores are specific to fungi classified as ascomycetes, which are ubiquitous in terrestrial ecosystems worldwide. Basidiospores are reproductive spores produced by basidiomycete fungi, and Ganoderma is a genus of polypore mushrooms which grow on wood. Figure 2 shows a comparison of these species (with Ganoderma included in the "Other" category) alongside the size-resolved image plots of each fluorescence channel from the two real-time fluorescence instruments. The correlation of total biological particle concentration (Sporewatch) with WIBS and UV-APS may, however, be more readily seen by comparing integrated number concentrations, as shown in Fig. 5. $N_{\mathrm{F}, \mathrm{c}}$ values determined individually by WIBS FL2, FL3, and UV-APS each show similar periods of high and low concentrations (Fig. 5b), though each channel is plotted with a different $y$ scale multiplier. This suggests that, despite the differing lists of fluorophores accessible to each channel, the groups of mi- croorganisms selected are similar. The differing magnitude to the numbers, however, suggests that individual particles in each group possessing lower fluorescence emission are likely to be undercounted by the measurements and that the sensitivity of the detection scheme is important. The rise and fall of the Sporewatch peaks at similar time periods of the FL2, FL3, and UV-APS $N_{\mathrm{F}, \mathrm{c}}$ suggests a good qualitative comparison between the techniques and that these channels of the real-time fluorescence instruments are indeed successful in detecting biological aerosols such as these fungal spores.

In contrast to the qualitative similarity of the temporal trends of the WIBS FL2, FL3, and UV-APS numbers with the spore concentrations, the WIBS FL1 numbers bear little temporal similarity (Fig. $5 \mathrm{a}$ ). $N_{\mathrm{F}, \mathrm{c}}$ from FL1 is influenced heavily by particles with $D<2 \mu \mathrm{m}$, which is collected less efficiently by the Sporewatch impactor. Thus the population of particles detected by FL1 is largely separate from that of the particles observed by the paired Sporewatch/microscopy technique. These could be single or agglomerated bacteria particles that would be expected to fluoresce after excitation by $280 \mathrm{~nm}$ light of the FL1 channel. Though bacteria were not counted directly by the Sporewatch technique and their numbers may not be accurately determined by the UV-APS or WIBS, the number of fluorescent particles $1-2 \mu \mathrm{m}$ in the WIBS FL1 channel is approx. $10^{5} \mathrm{~m}^{-3}$, which is an order of magnitude higher than $\sim 10^{4} \mathrm{~m}^{-3}$, commonly estimated as the concentration of bacteria present over vegetated surfaces (Bauer et al., 2002; Burrows et al., 2009b; Després et al., 2012). The cited studies estimated the concentration of bacteria over vegetated surfaces by reviewing a large number of reports collectively, each of which use different methods of detection, e.g., DNA sequencing, compared to the current work, which uses online particle autofluoresence detection. 
Thus, it is likely that bacteria were detected by the WIBS FL1 channel but that bacteria cannot explain all particles measured by the FL1 signal.

We hypothesize three other mechanisms by which observed Sporewatch numbers would be lower than the WIBS FL1 number. First, sea spray enriched in sub-micron organic material, including proteins and other biological degradation products (Prather et al., 2013), coating larger particles accounts for some of the FL1 particles and fluorescent coatings on particles observed via fluorescent microscopy. Second, low Sporewatch numbers are partially a result of hyaline particles not easily seen or counted using microscopy but which could still fluoresce. This mechanism is less likely, however, because the process of fluorescent excitation is limited to particles that absorb, and so an individual particle would be expected to absorb strongly at $280 \mathrm{~nm}$, but not in the visible $(>390 \mathrm{~nm})$. It is also unlikely that such biological particles would coincidentally fluoresce after $280 \mathrm{~nm}$ excitation but not fluoresce with $355-370 \mathrm{~nm}$ excitation at the same time as being missed by visual counting. A third and final mechanism to explain the discrepancy between FL1 and Sporewatch number concentrations is that the FL1 channel counts a much higher number of non-biological particles that reduce the correlation with spore concentrations. These particles could be certain types of absorbing brown carbon secondary organic aerosol (Bones et al., 2010; Gabey et al., 2013; Lee et al., 2013) or soot particles (Lewitzka and Niessner, 1995; Panne et al., 2000) adsorbed as coatings (Huffman et al., 2012) or as discreet particles of size $<2 \mu \mathrm{m}$.

A quantitative view of the same correlations is shown in Fig. 6: $N_{\mathrm{F}, \mathrm{c}}$ from each channel plotted against a subset of the Sporewatch number (all classes except Cladosporium). Comparing number concentrations from each LIF channel with spore concentrations, the UV-APS shows the highest correlation ( $R^{2}$ of 0.71 ), with $R^{2}$ values of $0.05,0.29$, and 0.38 for WIBS FL1, FL2, and FL3 channels, respectively. In each comparison, however, the spore numbers are shown to undercount the real-time fluorescence measured numbers by factors of 3 to 14 (see Fig. 6 caption). This undercounting is likely influenced heavily by the fact that the Sporewatch does not efficiently collect particles with $D<2 \mu \mathrm{m}$, a size range that contains significant particle numbers measured by several of the fluorescence channels (Fig. 3). The Sporewatch undercounting of small particles is unlikely to be the only cause of the scaling factor, however, because the UV-APS did not show significant fluorescent particles in this size range but still undercounted spores by a factor of 3 . As a result, it may indicate that other fluorescent bioparticles (e.g., bacteria) or non-biological particles in the same size range can be associated with the same air masses, and thus would increase $N_{\mathrm{F}, \mathrm{c}}$ but not the contemporaneous spore numbers.

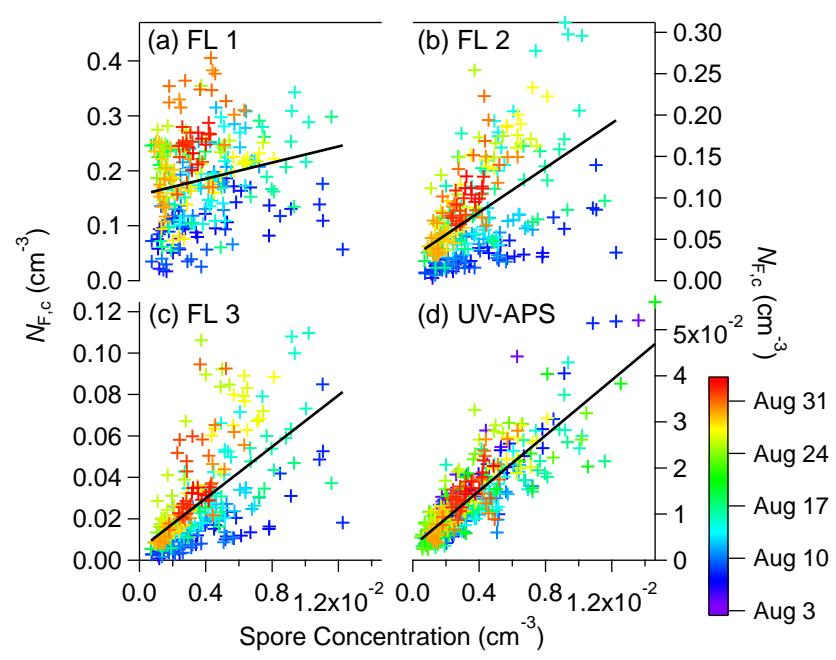

Figure 6. Demonstrated relationship of $N_{\mathrm{F}, \mathrm{C}}$ determined by the real-time instruments vs. a sum of a subset of spores collected by the Sporewatch impactor. Spores here include ascospores, basidiospores, and Ganoderma spp., which make up approx. $88 \%$ of total spore concentration (remaining percentage being Cladosporium spp.). Crosses represent $2 \mathrm{~h}$ measurement points, colored by sampling date. Black lines represent unweighted linear fits, with coefficients as follows: (a) FL1 $\left(m=7.67, R^{2}=0.052\right)$, (b) FL2 $\left(m=14.03, R^{2}=0.290\right)$, (c) FL3 $\left(m=6.47, R^{2}=0.380\right)$, and (d) UV-APS $\left(m=3.00, R^{2}=0.710\right)$. All vertical axes have different scales.

\subsection{Diurnal trends and atmospheric implications}

To highlight the similarity of each of the measurements styles, Fig. 7 shows diurnal $(24 \mathrm{~h})$ plots of spores observed (Fig. 7a) and of each fluorescence channel (Fig. 7b-e). Each measurement shows an increase in biological or fluorescent number concentration during the night and early morning hours (approx. 02:00-06:00 LT), with daily minima occurring in the mid-afternoon (approx. 15:00 LT). Figure 7 also shows the corresponding diurnal trend in relative humidity, which peaks at similar hours. This is consistent with commonly observed trends that many bioparticle classes correlate strongly with RH and peak at night due to active fungal emission mechanisms that require high humidity to function (e.g., Hirst, 1953; Rockett and Kramer, 1974; Huffman et al., 2012; Schumacher et al., 2013; Toprak and Schnaiter, 2013).

The UV-APS and WIBS FL3 channels each show monomodal size distributions peaking at 3-4 $\mu \mathrm{m}$ through the night, while the FL2 channel shows a bimodal distribution peaking at approx. $1 \mu \mathrm{m}$ and $3-4 \mu \mathrm{m}$ in size. These diurnal trends are reflected strongly by the concentrations of basidiospores, and even more so by ascospores. Based on the observations via optical microscopy, the larger species ( $D \sim 3-4 \mu \mathrm{m}$ ) identified by the real-time fluorescence techniques are likely to be basidiospores and Ganoderma spp., while the smaller mode ( $D$ approx. $1 \mu \mathrm{m}$ ) observed for the 

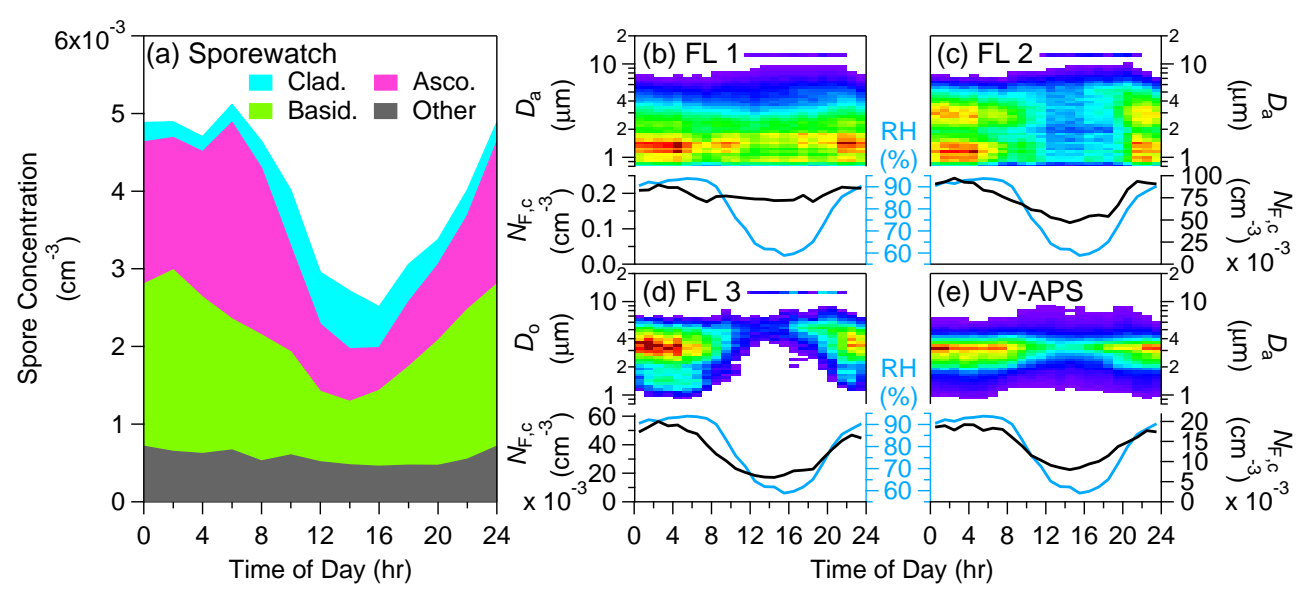

Figure 7. Diurnal plots of number concentrations from Sporewatch (a) and real-time fluorescence instruments (b-e) as median values for entire sampling period. For panels (b-e), upper half of each panel shows size-resolved number concentration trends, with color scale qualitatively similar to Fig. 2 (warmer colors, higher concentration). Lower half of each panel shows integrated fluorescent particle number $\left(N_{\mathrm{F}, \mathrm{c}}, D>1 \mu \mathrm{m}\right)$ as the black trace and relative humidity as the blue trace. Vertical scale on $N_{\mathrm{F}, \mathrm{c}}$ axes not consistent. $N_{\mathrm{F}, \mathrm{c}}$ scale for (c-e) shown expanded by $10^{3}$.

FL2 channel may be comprised of ascospores. However, the identity of the smaller fluorescent particles is more uncertain, because the particles are relatively unidentifiable via optical microscopy because of insufficient magnification. Huffman et al. (2012) argue, using diurnal measurements and comparison with previous literature reports, that $N_{\mathrm{F}, \mathrm{c}}$ from UVAPS observations in the Amazon rainforest are most likely to be a mixture of ascospores and basidiospores. Though measurements were conducted in a very different ecosystem, the conclusions here are consistent with earlier suggestions that UV-LIF measurements are particularly well suited to the detection of these bioparticle classes. Further, Manninen et al. (2014) present multi-year Sporewatch measurements in Hyytiälä, Finland, and show that late summer (August and September) in northern Europe is a peak season for many spores, including several groups of ascospores and basidiospores. Comparison with long-term UV-APS measurements reported by Schumacher et al. (2013) and Manninen et al. (2014) suggests these classes of spores peak on a similar yearly cycle to the UV-APS $N_{\mathrm{F}, \mathrm{c}}$, and thus the August measurement period in this study coincides with a period of the year consistent with high fungal spore concentrations. Further, the fungal spore concentrations reported by Manninen et al. (2014) of $1-10 \times 10^{4} \mathrm{~m}^{-3}\left(1-10 \times 10^{-2} \mathrm{~cm}^{-3}\right)$ are within an order of magnitude of Sporewatch numbers reported here $0.1-1 \times 10^{-2} \mathrm{~cm}^{-3}$.

Diurnal patterns for additional meteorological measurements (e.g., air temperature, solar radiation, atmospheric pressure, and wind speed) observed during the entire measurement period are shown in Fig. S4 in the Supplement. A consistent diurnal cycle was observed for RH with nighttime periods (campaign max. 98\%) reaching higher values than during the day (campaign min. $38 \%$ ). Minimum and maximum air temperatures recorded during the campaign were 4 and $26^{\circ} \mathrm{C}$, respectively, with a campaign average of $15^{\circ} \mathrm{C}$. Generally calm weather conditions, with several short periods of rain, were encountered throughout the entire campaign. This general pattern was reflected meteorologically by the lack of observable diurnal patterns for atmospheric pressure and also by low wind speeds.

\subsection{Weakly detected Cladosporium spores}

In contrast to the diurnal trend of the ascospores and basidiospores, the "Other" category shows relatively flat diurnal profile, and the concentration of Cladosporium spp. spores, which are among the most common spore types in vegetated areas, shows a relative increase during the middle of the afternoon (peaking approx. 14:00). This temporal pattern for Cladosporium is expected and has been reported frequently. It is usually considered to be a dry weather spore whose concentration increases during warm periods of low relative humidity (De Groot, 1968; Oliveira et al., 2009). The interesting observation here is that the real-time fluorescence methods are relatively insensitive to the increases in Cladosporium spore concentration. Correlation plots of each fluorescence channel with Cladosporium spores show no qualitative pattern, with $R^{2}$ values $<0.006$ in all cases. The reason for the relative insensitivity of these techniques to Cladosporium is unknown, but may relate to the dark-skinned (i.e., absorbing) nature of these spores preventing impinging photons from penetrating exterior pigments to excite fluorescence from internal fluorophores (Bell-Pedersen et al., 1996). 


\subsection{Marine particle influence}

Fluorescence microscopy images of size-resolved MOUDI stages collected during the study qualitatively show the presence of spores and other biological particles. The particles in the size range $>2 \mu \mathrm{m}$ observed by the fluorescent microscopy technique to have the highest fluorescence were identified morphologically as PBAPs. Many of the strongly fluorescent PBAPs also demonstrated a clear cell wall fluorescence, which suggests that it is not the cytosol or cellular metabolites such as $\mathrm{NAD}(\mathrm{P}) \mathrm{H}$ or riboflavin but structural components of the cell wall that dominate the emission (Pöhlker et al., 2012, 2013). Many of the fluorescent PBAPs also demonstrated fungal spore-like morphologies. Also frequently observed, however, were cubic particles that appear morphologically similar to $\mathrm{NaCl}$ (Fig. 8), and needle-like particles consistent with structures of crystals such as $\mathrm{CaSO}_{4}$. No elemental analysis was possible on these particle agglomerates for confirmation, however. The observations of these inorganic-appearing particles suggest the influence of marine air containing sea salt. Of further interest is the appearance of bioparticles attached to the cubic salt-like particles, in which cases the bioparticle typically fluoresces strongly whereas the sea-salt-like crystals do not. The number concentration of bioparticles and sea salt in the coarse particle mode make the agglomeration of these particles while airborne statistically unlikely. Thus, we suggest that the bioparticle-salt agglomerates were likely emitted by marine sources and transported approx. $20 \mathrm{~km}$ from the ocean west of Ireland (Kenny and Jennings, 1998; Aller et al., 2005).

\section{Conclusions}

The study shows the measurement capabilities of the WIBS4 and UV-APS to detect biological particles in a rural, ambient location and is the first to compare these two commercial sensors. Information revealed by each instrument is qualitatively similar, but key differences are apparent. Total coarse particle concentration $\left(N_{\mathrm{T}, \mathrm{c}}\right)$ was shown to correlate well between the two instruments, and size distributions of total particles were similar. The UV-APS sizing measurement (aerodynamic diameter) showed more highly resolved distributions than did the WIBS-4 (optical diameter). This is likely a function of the physical properties of the particle sizing schemes in each instrument, and has been suggested previously. The minimum particle size detected by the WIBS-4, however, is related to the trigger threshold selected by the operator.

Concentrations of fluorescent particles observed during the measurement period by both instruments show regular, diurnal fluctuations that are qualitatively similar to each other. However, differences in excitation/emission wavelength result in different particle populations observed. The UV-APS ( $\left.\lambda_{\text {ex }} 355 \mathrm{~nm}\right)$ and WIBS FL3 channel $\left(\lambda_{\text {ex }} 370 \mathrm{~nm}\right)$
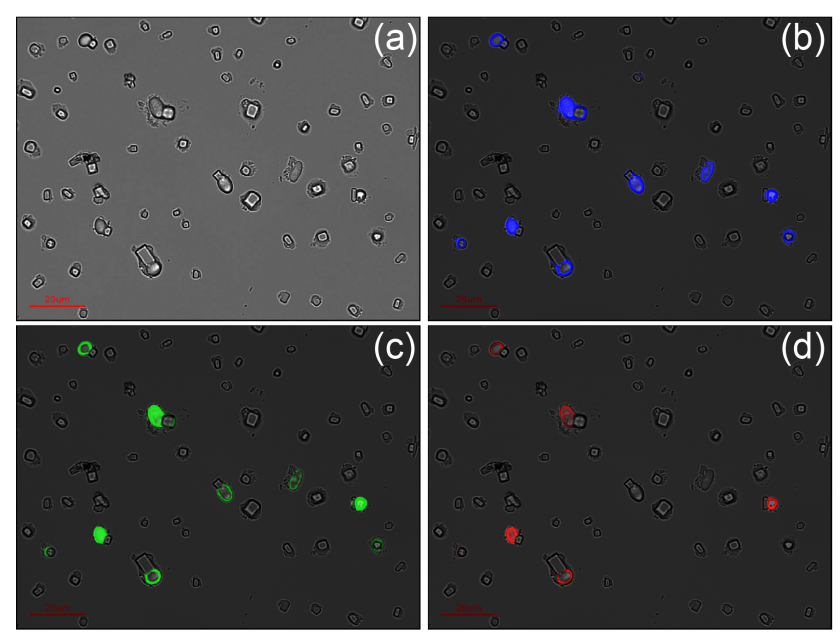

Figure 8. Fluorescence microscopy images of ambient aerosols collected on MOUDI stage 5 (size range, $D$ 1.0-1.8 $\mu \mathrm{m}$ ) on 25 August, 03:00-07:00 (LT). Illumination source: (a) bright field; (b) $\lambda_{\mathrm{ex}}=340-380 \mathrm{~nm}, \lambda_{\mathrm{em}}=435-485$; (c) $\lambda_{\mathrm{ex}}=465-495 \mathrm{~nm}$, $\lambda_{\mathrm{em}}=510-560$; and (d) $\lambda_{\mathrm{ex}}=540-580 \mathrm{~nm}, \lambda_{\mathrm{em}}=600-660$. Magnification $\times 1000$.

correlate strongly, suggesting that the relative proximity of the excitation wavelengths allows each of these channels to excite similar fluorophores within interrogated particles. The UV-APS and WIBS FL3 channel show fluorescent particles dominated by a mode peaking at approx. $3 \mu \mathrm{m}$, with additional presence of a mode at approx. $1 \mu \mathrm{m}$ present in FL3. However, the UV-APS $N_{\mathrm{F}, \mathrm{c}}$ was lower than FL3 $N_{\mathrm{F}, \mathrm{c}}$ by a factor of approx. 2.4, suggesting that the UV-APS particle detection sensitivity was relatively poor.

The WIBS FL2 channel showed a consistently bimodal distribution comprised of 1 and $3 \mu$ m modes and qualitatively appears to be a combination of modes present in the FL1 and FL3 channels. The WIBS FL2, FL3, and UV-APS particle numbers correlated well in time and number with spore numbers collected via Sporewatch impactor and enumerated via optical microscopy. Each showed a diurnal peak in the early morning, with daily minima in the mid-afternoon.

The WIBS FL1 channel, however, showed very different patterns. FL1 showed a relatively consistent diurnal pattern and a multimodal size distribution with the highest concentration of fluorescent particles observed by any channel, but with the poorest correlation with spore numbers. This arises partially because $N_{\mathrm{F}, \mathrm{c}}$ from FL1 was summed of particles with $D>1 \mu \mathrm{m}$, whereas the Sporewatch impaction technique is relatively inefficient at collecting particles $<2 \mu \mathrm{m}$. The smaller particles that escape Sporewatch detection but are recorded by the FL1 channel $\left(\lambda_{\mathrm{ex}} 270 \mathrm{~nm}\right)$ may include bacterial cells and protein-enriched coatings from sea spray origin. However, the discrepancy could also indicate the detection of non-biological particles such as certain absorbing SOA or soot into the FL1 particle number. It is thus clear 
from these observations that the multiple channels of fluorescent information delivered by the WIBS provide an advantage over the single fluorescence channel of the UV-APS. The qualitative similarity of diurnal patterns and of the UVAPS with WIBS FL3 channels highlights the utility of the UV-APS to detect the overall trends of fluorescent biological particles, however.

Comparisons between the real-time fluorescence instruments and the Sporewatch/microscopy technique reveal that the most likely species of airborne microorganism $(D>2 \mu \mathrm{m})$ present in Killarney National Park during the measurement period were spores, including basidiospores, ascospores, Ganoderma spp., and Cladosporium spp. The correlation of total spore concentration with the WIBS FL2, FL3, and UV-APS $N_{\mathrm{F}, \mathrm{c}}$ was high. However, Cladosporium spores correlated extremely poorly with all fluorescent measurements, suggesting that dark-walled cell walls may inhibit real-time fluorescence detection. Despite the presence of the spores observed, the microscopy results cannot rule out the possible contribution of soil bacteria such as actinobacteria and streptomycetes in the size range $1-2 \mu \mathrm{m}$ that is not efficiently collected by the Sporewatch. These commonly airborne PBAP classes could also contribute to $N_{\mathrm{F}, \mathrm{c}}$ and reduce correlation with Sporewatch number.

The results of this study show that both WIBS and UVAPS techniques are capable of providing real-time information about biological aerosol particles, and that they can relate the major temporal trends of airborne fungal spores. Significant uncertainties still remain in the interpretation of the data from these instruments, and follow-up studies (e.g., systematic comparisons of the instruments in a controlled laboratory setting) will be necessary to inform further studies and analysis. For example, further work will be required to understand the nature of the poor correlation between spore concentration and WIBS FL1 number. Additional followup work will also be necessary to understand WIBS triggering thresholds to best characterize both fluorescent and non-fluorescent aerosol in field environments with unknown aerosol. These data show that the instruments performed well in a relatively clean, rural national park in western Ireland, but operational considerations will likely be different at sites more heavily influenced by anthropogenic aerosol sources. On the other hand, UV-APS detected few of the smaller bacterial PBAPs because of its single excitation wavelength. Measurements such as those presented here may provide direct inputs for the improvement of global models investigating the role of PBAPs as ice or cloud condensation nuclei.

Relatively few estimates of PBAP concentrations exist, and the present study provides measured concentrations in a rural European environment. Further, the comparison of realtime fluorescence techniques capable of detecting fluorescent biological particles at high time- and size resolution are supported by good correlations with direct observations of particles using optical microscopy (bright field and fluorescence). These data support the idea that real-time fluorescence tech- niques can significantly improve time resolution and analysis time of traditional PBAP identification, which can be very laborious, time consuming, and costly. Spore concentrations were observed on the order of $1-10 \times 10^{4} \mathrm{~m}^{-3}$, which is consistent with previous estimates (e.g., Elbert et al., 2007; Després et al., 2012; Manninen et al., 2014). Bacteria concentrations were not directly measured by these techniques, but the number of $1-2 \mu \mathrm{m}$ particles in the WIBS FL1 channel is on the order of $10^{5} \mathrm{~m}^{-3}$, which could easily encompass the $\sim 10^{4} \mathrm{~m}^{-3}$ of bacteria commonly estimated to be present as a continental background concentration (Bauer et al., 2002; Burrows et al., 2009b; Després et al., 2012). Observations that spore and FBAP concentrations cycle on a daily basis with RH and inversely with temperature are consistent with many previous reports that suggest many classes of fungal spores utilize periods of high humidity for active release (Jones and Harrison, 2004; Pringle et al., 2005; Elbert et al., 2007). Lastly, fluorescent microscopy images of sea-salt-like particles agglomerated with biological cells suggest that air at the site was influenced by marine air and that the ocean provides one source of airborne biological material.

\section{The Supplement related to this article is available online at doi:10.5194/acp-14-8055-2014-supplement.}

Acknowledgements. The authors acknowledge the National Parks and Wildlife Service of Ireland for providing a sampling location in Killarney National Park with a suitable power supply. This work was financially supported by the Irish EPA BioCheA 2007 CCRP Project 4.4.6 and STRIVE doctoral training program (2008PhD-AQ-2). Financial support for J. A. Huffman, C. Pöhlker, and U. Pöschl was from the Max Planck Society, the Max Planck Graduate Center with the Johannes Gutenberg-Universität Mainz (MPGC), and the LEC Geocycles Mainz. J. A. Huffman acknowledges internal faculty funding from the University of Denver. The authors also acknowledge J. Schneider and S. Borrmann (MPIC Particle Chemistry) for providing a UV-APS instrument, and Eoin McGillicuddy, Ian O'Connor, and Arnaud Allanic for help with the mobile laboratory and help transporting equipment. P. Kaye, W. Stanley, and D. Dodd are acknowledged for their support of the BioCheA project.

Edited by: J. Allan

\section{References}

Aller, J. Y., Kuznetsova, M. R., Jahns, C. J., and Kemp, P. F.: The sea surface microlayer as a source of viral and bacterial enrichment in marine aerosols, J. Aerosol Sci., 36, 801-812, doi:10.1016/j.jaerosci.2004.10.012, 2005.

Bauer, H., Kasper-Giebl, A., Löflund, M., Giebl, H., Hitzenberger, R., Zibuschka, F., and Puxbaum, H.: The contribution of bacteria and fungal spores to the organic carbon content of cloud water, precipitation and aerosols, Atmos. Res., 64, 109-119, 2002. 
Bell-Pedersen, D., Garceau, N., and Loros, J. J.: Circadian rhythms in fungi, J. Genet., 75, 387-401, 1996.

Bones, D. L., Henricksen, D. K., Mang, S. A., Gonsior, M., Bateman, A. P., Nguyen, T. B., Cooper, W. J., and Nizkorodov, S. A.: Appearance of strong absorbers and fluorophores in limonene-O-3 secondary organic aerosol due to $\mathrm{NH}_{4}+$-mediated chemical aging over long time scales, J. Geophys. Res.-Atmos., 115, D05203, doi:10.1029/2009jd012864, 2010.

Brosseau, L. M., Vesley, D., Rice, N., Goodell, K., Nellis, M., and Hairston, P.: Differences in detected fluorescence among several bacterial species measured with a direct-reading particle sizer and fluorescence detector, Aerosol Sci. Tech., 32, 545-558, 2000.

Burrows, S. M., Butler, T., Jöckel, P., Tost, H., Kerkweg, A., Pöschl, U., and Lawrence, M. G.: Bacteria in the global atmosphere - Part 2: Modeling of emissions and transport between different ecosystems, Atmos. Chem. Phys., 9, 9281-9297, doi:10.5194/acp-9-9281-2009, 2009a.

Burrows, S. M., Elbert, W., Lawrence, M. G., and Pöschl, U.: Bacteria in the global atmosphere - Part 1: Review and synthesis of literature data for different ecosystems, Atmos. Chem. Phys., 9, 9263-9280, doi:10.5194/acp-9-9263-2009, 2009b.

Caruana, D. J.: Detection and analysis of airborne particles of biological origin: present and future, Analyst, 136, 4641-4652, doi:10.1039/c1an15506g, 2011.

Christner, B. C., Morris, C. E., Foreman, C. M., Cai, R. M., and Sands, D. C.: Ubiquity of biological ice nucleators in snowfall, Science, 319, 1214-1214, doi:10.1126/science.1149757, 2008.

De Groot, R. C.: Diurnal cycles of airborne spores produced by forest fungi, Phytopathology, 58, 1223-1229, 1968.

DeLeon-Rodriguez, N., Lathem, T. L., Rodriguez-R, L. M., Barazesh, J. M., Anderson, B. E., Beyersdorf, A. J., Ziemba, L. D., Bergin, M., Nenes, A., and Konstantinidis, K. T.: Microbiome of the upper troposphere: Species composition and prevalence, effects of tropical storms, and atmospheric implications, P. Natl. Acad. Sci. USA, 110, 2575-2580, doi:10.1073/pnas.1212089110, 2013.

Després, V. R., Huffman, J. A., Burrows, S. M., Hoose, C., Safatov, A. S., Buryak, G. A., Fröhlich-Nowoisky, J., Elbert, W., Andreae, M. O., Pöschl, U., and Jaenicke, R.: Primary Biological Aerosol Particles in the Atmosphere: A Review, Tellus B, 64, 15598, doi:10.3402/tellusb.v64i0.15598, 2012.

Diehl, K., Quick, C., Matthias-Maser, S., Mitra, S. K., and Jaenicke, R.: The ice nucleating ability of pollen - Part I: Laboratory studies in deposition and condensation freezing modes, Atmos. Res., 58, 75-87, 2001.

Elbert, W., Taylor, P. E., Andreae, M. O., and Pöschl, U.: Contribution of fungi to primary biogenic aerosols in the atmosphere: wet and dry discharged spores, carbohydrates, and inorganic ions, Atmos. Chem. Phys., 7, 4569-4588, doi:10.5194/acp-7-4569-2007, 2007.

Eng, J., Lynch, R. M., and Balaban, R. S.: Nicotinamide Adenine Dinucleotide Fluorescence Spectroscopy and Imaging of Isolated Cardiac Myocytes, Biophys. J., 55, 621-630, 1989.

Eversole, J. D., Hardgrove, J. J., Cary, W. K., Choulas, D. P., and Seaver, M.: Continuous, rapid biological aerosol detection with the use of UV fluorescence: Outdoor test results, Field Anal. Chem. Tech., 3, 249-259, 1999.
Foot, V. E., Kaye, P. H., Stanley, W. R., Barrington, S. J., Gallagher, M., and Gabey, A.: Low-cost real-time multiparameter bio-aerosol sensors, Proceedings of the SPIE - The International Society for Optical Engineering, 7116, 711601, doi:10.1117/12.800226, 2008.

Fröhlich-Nowoisky, J., Pickersgill, D. A., Despés, R. V., and Pöschl, U.: High diversity of fungi in air particulate matter, P. Natl. Acad. Sci., 106, 12814-12819, doi:10.1073/pnas.0811003106, 2009.

Fröhlich-Nowoisky, J., Burrows, S. M., Xie, Z., Engling, G., Solomon, P. A., Fraser, M. P., Mayol-Bracero, O. L., Artaxo, P., Begerow, D., Conrad, R., Andreae, M. O., Després, V. R., and Pöschl, U.: Biogeography in the air: fungal diversity over land and oceans, Biogeosciences, 9, 1125-1136, doi:10.5194/bg9-1125-2012, 2012.

Gabey, A. M., Gallagher, M. W., Whitehead, J., Dorsey, J. R., Kaye, P. H., and Stanley, W. R.: Measurements and comparison of primary biological aerosol above and below a tropical forest canopy using a dual channel fluorescence spectrometer, Atmos. Chem. Phys., 10, 4453-4466, doi:10.5194/acp-10-4453-2010, 2010.

Gabey, A. M., Stanley, W. R., Gallagher, M. W., and Kaye, P. H.: The fluorescence properties of aerosol larger than $0.8 \mu \mathrm{m}$ in urban and tropical rainforest locations, Atmos. Chem. Phys., 11, 5491-5504, doi:10.5194/acp-11-5491-2011, 2011.

Gabey, A. M., Vaitilingom, M., Freney, E., Boulon, J., Sellegri, K., Gallagher, M. W., Crawford, I. P., Robinson, N. H., Stanley, W. R., and Kaye, P. H.: Observations of fluorescent and biological aerosol at a high-altitude site in central France, Atmos. Chem. Phys., 13, 7415-7428, doi:10.5194/acp-13-7415-2013, 2013.

Haga, D. I., Iannone, R., Wheeler, M. J., Mason, R., Polishchuk, E. A., Fetch Jr., T., van der Kamp, B. J., McKendry, I. G., and Bertram, A. K.: Ice nucleation properties of rust and bunt fungal spores and their transport to high altitudes, where they can cause heterogeneous freezing, J. Geophys. Res.-Atmos., 118, 72607272, doi:10.1002/jgrd.50556, 2013.

Hairston, P. P., Ho, J., and Quant, F. R.: Design of an instrument for real-time detection of bioaerosols using simultaneous measurement of particle aerodynamic size and intrinsic fluorescence, J. Aerosol Sci., 28, 471-482, 1997.

Harrison, D. E. and Chance, B.: Fluorimetric Technique for Monitoring Changes in Level of Reduced Nicotinamide Nucleotides in Continuous Cultures of Microorganisms, Appl. Microbiol., 19, 446-450, 1970.

Heald, C. L. and Spracklen, D. V.: Atmospheric budget of primary biological aerosol particles from fungal spores, Geophys. Res. Lett., 36, L09806, doi:10.1029/2009g1037493, 2009.

Healy, D. A., O'Connor, D. J., Burke, A. M., and Sodeau, J. R.: A laboratory assessment of the Waveband Integrated Bioaerosol Sensor (WIBS-4) using individual samples of pollen and fungal spore material, Atmos. Environ., 60, 534-543, doi:10.1016/j.atmosenv.2012.06.052, 2012a.

Healy, D. A., O'Connor, D. J., and Sodeau, J. R.: Measurement of the particle counting efficiency of the "Waveband Integrated Bioaerosol Sensor" model number 4 (WIBS-4), J. Aerosol Sci., 47, 94-99, doi:10.1016/j.jaerosci.2012.01.003, 2012b.

Hill, S. C., Pinnick, R. G., Niles, S., Fell, N. F., Pan, Y. L., Bottiger, J., Bronk, B. V., Holler, S., and Chang, R. K.: Fluorescence from airborne microparticles: dependence on size, concentration of fluorophores, and illumination intensity, Appl. Optics, 40, 3005-3013, 2001. 
Hirst, J. M.: An Automatic Volumetric Spore Trap, Ann. Appl. Biol., 39, 257-265, doi:10.1111/j.1744-7348.1952.tb00904.x, 1952.

Hirst, J. M.: Changes in atmospheric spore content: Diurnal periodicity and the effects of weather, T. Brit. Mycol. Soc., 36, 375393, doi:10.1016/s0007-1536(53)80034-3, 1953.

Ho, J.: Future of biological aerosol detection, Anal. Chim. Acta, 457, 125-148, 2002.

Hoose, C., Kristjansson, J. E., and Burrows, S. M.: How important is biological ice nucleation in clouds on a global scale?, Environ. Res. Lett., 5, 024009, doi:10.1088/1748-9326/5/2/024009, 2010.

Huffman, J. A., Treutlein, B., and Pöschl, U.: Fluorescent biological aerosol particle concentrations and size distributions measured with an Ultraviolet Aerodynamic Particle Sizer (UVAPS) in Central Europe, Atmos. Chem. Phys., 10, 3215-3233, doi:10.5194/acp-10-3215-2010, 2010.

Huffman, J. A., Sinha, B., Garland, R. M., Snee-Pollmann, A., Gunthe, S. S., Artaxo, P., Martin, S. T., Andreae, M. O., and Pöschl, U.: Size distributions and temporal variations of biological aerosol particles in the Amazon rainforest characterized by microscopy and real-time UV-APS fluorescence techniques during AMAZE-08, Atmos. Chem. Phys., 12, 11997-12019, doi:10.5194/acp-12-11997-2012, 2012.

Huffman, J. A., Prenni, A. J., DeMott, P. J., Pöhlker, C., Mason, R. H., Robinson, N. H., Fröhlich-Nowoisky, J., Tobo, Y., Després, V. R., Garcia, E., Gochis, D. J., Harris, E., Müller-Germann, I., Ruzene, C., Schmer, B., Sinha, B., Day, D. A., Andreae, M. O., Jimenez, J. L., Gallagher, M., Kreidenweis, S. M., Bertram, A. K., and Pöschl, U.: High concentrations of biological aerosol particles and ice nuclei during and after rain, Atmos. Chem. Phys., 13, 6151-6164, doi:10.5194/acp-13-6151-2013, 2013.

Hummel, M., Hoose, C., Gallagher, M., Healy, D. A., Huffman, J. A., O'Connor, D., Pöschl, U., Pöhlker, C., Robinson, N. H., Schnaiter, M., Sodeau, J. R., Toprak, E., and Vogel, H.: Regionalscale simulations of fungal spore aerosols using an emission parameterization adapted to local measurements of fluorescent biological aerosol particles, Atmos. Chem. Phys. Discuss., 14, 9903-9950, doi:10.5194/acpd-14-9903-2014, 2014.

Jones, A. M. and Harrison, R. M.: The effects of meteorological factors on atmospheric bioaerosol concentrations - a review, Sci. Total Environ., 326, 151-180, 10.1016/j.scitotenv.2003.11.021, 2004.

Kaye, P. H., Stanley, W. R., Hirst, E., Foot, E. V., Baxter, K. L., and Barrington, S. J.: Single particle multichannel bio-aerosol fluorescence sensor, Opt. Express, 13, 3583-3593, 2005.

Kelly, D. L.: The native forest vegetation of Killarney, south-west Ireland: and ecological account, J. Ecol., 69, 437-472, 1981.

Kenny, C. M. and Jennings, S. G.: Background bioaerosol measurements at Mace Head, J. Aerosol Sci., 29, S779-S780, doi:10.1016/S0021-8502(98)90572-9, 1998.

Khattab, A. and Levetin, E.: Preliminary studies on the effect of the Burkard alternate orifice on airborne fungal spore concentrations, Aerobiologia, 24, 165-171, 2008.

Lacey, J. and Dutkiewicz, J.: Bioaerosols and Occupational Lung Disease, J. Aerosol Sci., 25, 1371-1404, 1994.

Lacey, J. and Venette, J.: Outdoor Air Sampling Techniques, in: Bioaerosols Handbook, edited by: Cox, C. S. and Wathes, C. M., Lewis Publishers, Boca Raton, FL, 407-471, 1995.
Lacey, M. E. and West, J. S.: The air spora: a manual for catching and identifying airborne biological particles, Springer, 2007.

Lee, H. J., Laskin, A., Laskin, J., and Nizkorodov, S. A.: ExcitationEmission Spectra and Fluorescence Quantum Yields for Fresh and Aged Biogenic Secondary Organic Aerosols, Environ. Sci. Technol., 47, 5763-5770, doi:10.1021/es400644c, 2013.

Lewitzka, F. and Niessner, R.: Application of Time-Resolved Fluorescence Spectroscopy on the Analysis of PAHCoated Aerosols, Aerosol Sci. Tech., 23, 454-464, doi:10.1080/02786829508965328, 1995.

Li, J. K., Asali, E. C., and Humphrey, A. E.: Monitoring Cell Concentration and Activity by Multiple Excitation Flourometry, Biotechnol. Progr., 7, 21-27, 1991.

Madelin, T. M.: Fungal Aerosols - A Review, J. Aerosol Sci., 25, 1405-1412, doi:10.1016/0021-8502(94)90216-x, 1994.

Maki, L. R., Glyan, E. L., Chang-Chien, M. M., and Caldwell, D. R.: Ice nucleation induced by Pseudomonas syringae, Appl. Environ. Microb., 28, 456-459, 1974.

Manninen, H. E., Sihto-Nissilä, S.-L., Huffman, J. A., Bäck, J., Pessi, A.-M., Hiltunen, V., Aalto, P., Hidalgo, P. J., Hari, P., Saarto, A., Kulmala, M., and Petäjä, T.: Annual pattern of airborne pollen grains, fungal spores and particle mass in a boreal forest, Boreal Environ. Res., in review, 2014.

Marple, V. A., Rubow, K. L., and Behm, S. M.: A microorifice uniform deposit impactor (MOUDI) - description, calibration, and use, Aerosol Sci. Tech., 14, 434-446, doi:10.1080/02786829108959504, 1991.

Möhler, O., DeMott, P. J., Vali, G., and Levin, Z.: Microbiology and atmospheric processes: the role of biological particles in cloud physics, Biogeosciences, 4, 1059-1071, doi:10.5194/bg-4-10592007, 2007.

Morris, C. E., Georgakopoulos, D. G., and Sands, D. C.: Ice nucleation active bacteria and their potential role in precipitation, $\mathrm{J}$. Phys. IV, 121, 87-103, doi:10.1051/jp4:2004121004, 2004.

Morris, C. E., Sands, D. C., Vinatzer, B. A., Glaux, C., Guilbaud, C., Buffiere, A., Yan, S., Dominguez, H., and Thompson, B. M.: The life history of the plant pathogen Pseudomonas syringae is linked to the water cycle, ISME J., 2, 321-334, 2008.

Morris, C. E., Sands, D. C., Glaux, C., Samsatly, J., Asaad, S., Moukahel, A. R., Gonçalves, F. L. T., and Bigg, E. K.: Urediospores of rust fungi are ice nucleation active at $>-10{ }^{\circ} \mathrm{C}$ and harbor ice nucleation active bacteria, Atmos. Chem. Phys., 13, 4223-4233, doi:10.5194/acp-13-4223-2013, 2013.

Morris, C. E., Conen, F., Huffman, J. A., Phillips, V., Pöschl, U., and Sands, D. C.: Bioprecipitation: a feedback cycle linking Earth history, ecosystem dynamics and land use through biological ice nucleators in the atmosphere, Glob. Change Biol., 20, 341-351, 10.1111/gcb.12447, 2014.

Oliveira, M., Ribeiro, H., Delgado, J., and Abreu, I.: The effects of meteorological factors on airborne fungal spore concentration in two areas differing in urbanisation level, Int. J. Biometeorol., 53, 61-73, doi:10.1007/s00484-008-0191-2, 2009.

Pan, Y. L., Pinnick, R. G., Hill, S. C., Rosen, J. M., and Chang, R. K.: Single-particle laser-induced-fluorescence spectra of biological and other organic-carbon aerosols in the atmosphere: Measurements at New Haven, Connecticut, and Las Cruces, New Mexico, J. Geophys. Res.-Atmos., 112, D24S19, doi:10.1029/2007jd008741, 2007. 
Pan, Y.-L., Hill, S. C., Pinnick, R. G., House, J. M., Flagan, R. C., and Chang, R. K.: Dual-excitation-wavelength fluorescence spectra and elastic scattering for differentiation of single airborne pollen and fungal particles, Atmos. Environ., 45, 1555-1563, doi:10.1016/j.atmosenv.2010.12.042, 2011.

Panne, U., Knöller, A., Kotzick, R., and Niessner, R.: On-line and in-situ detection of polycyclic aromatic hydrocarbons (PAH) on aerosols via thermodesorption and laser-induced fluorescence spectroscopy, Fresen. J. Anal. Chem., 366, 408-414, doi:10.1007/s002160050083, 2000.

Patel, N. J. and Bush, R. K.: Role of environmental allergens in rhinitis, Immunol. Allergy Clin., 20, 323-353, doi:10.1016/S0889-8561(05)70151-X, 2000.

Pinnick, R. G., Hill, S. C., Nachman, P., Pendleton, J. D., Fernandez, G. L., Mayo, M. W., and Bruno, J. G.: Fluorescence Particle Counter for Detecting Airborne Bacteria and Other Biological Particles, Aerosol Sci. Tech., 23, 653-664, 1995.

Pinnick, R. G., Hill, S. C., Pan, Y. L., and Chang, R. K.: Fluorescence spectra of atmospheric aerosol at Adelphi, Maryland, USA: measurement and classification of single particles containing organic carbon, Atmos. Environ., 38, 1657-1672, doi:10.1016/j.atmosenv.2003.11.017, 2004.

Pöhlker, C., Huffman, J. A., and Pöschl, U.: Autofluorescence of atmospheric bioaerosols - fluorescent biomolecules and potential interferences, Atmos. Meas. Tech., 5, 37-71, doi:10.5194/amt-537-2012, 2012.

Pöhlker, C., Huffman, J. A., Förster, J.-D., and Pöschl, U.: Autofluorescence of atmospheric bioaerosols: spectral fingerprints and taxonomic trends of pollen, Atmos. Meas. Tech., 6, 3369-3392, doi:10.5194/amt-6-3369-2013, 2013.

Pöschl, U.: Atmospheric aerosols: Composition, transformation, climate and health effects, Angew. Chem. Int. Edit., 44, 75207540, doi:10.1002/anie.200501122, 2005.

Pöschl, U., Martin, S. T., Sinha, B., Chen, Q., Gunthe, S. S., Huffman, J. A., Borrmann, S., Farmer, D. K., Garland, R. M., Helas, G., Jimeney, J. L., King, S. M., Manzi, A., Mikhailov, E., Pauliquevis, T., Petters, M. D., Prenni, A. J., Roldin, P., Rose, D., Schneider, J., Su, H., Zorn, S. R., Artaxo, P., and Andreae, M. O.: Rainforest Aerosols as Biogenic Nuclei of Clouds and Precipitation in the Amazon, Science, 329, 15131516, doi:10.1126/science.1191056, 2010.

Prather, K. A., Bertram, T. H., Grassian, V. H., Deane, G. B., Stokes, M. D., DeMott, P. J., Aluwihare, L. I., Palenik, B. P., Azam, F., and Seinfeld, J. H.: Bringing the ocean into the laboratory to probe the chemical complexity of sea spray aerosol, P. Natl. Acad. Sci., 110, 7550-7555, 2013.

Prenni, A. J., Tobo, Y., Garcia, E., DeMott, P. J., Huffman, J. A., McCluskey, C. S., Kreidenweis, S. M., Prenni, J. E., Pöhlker, C., and Pöschl, U.: The impact of rain on ice nuclei populations at a forested site in Colorado, Geophys. Res. Lett., 40, 227-231, doi:10.1029/2012g1053953, 2013.

Pringle, A., Patek, S. N., Fischer, M., Stolze, J., and Money, N. P.: The captured launch of a ballistospore, Mycologia, 97, 866-871, doi:10.3852/mycologia.97.4.866, 2005.

Pummer, B. G., Bauer, H., Bernardi, J., Bleicher, S., and Grothe, H.: Suspendable macromolecules are responsible for ice nucleation activity of birch and conifer pollen, Atmos. Chem. Phys., 12, 2541-2550, doi:10.5194/acp-12-2541-2012, 2012.
Robinson, N. H., Allan, J. D., Huffman, J. A., Kaye, P. H., Foot, V. E., and Gallagher, M.: Cluster analysis of WIBS single-particle bioaerosol data, Atmos. Meas. Tech., 6, 337-347, doi:10.5194/amt-6-337-2013, 2013.

Rockett, T. R. and Kramer, C. L.: Periodicity and Total Spore Production by Lignicolous basidiomycetes, Mycologia, 66, 817829, 1974.

Sands, D. C., Langhans, V. E., Scharen, A. L., and de Smet, G.: The association between bacteria and rain and possible resultant meteorological implications, Journal of the Hungarian Meteorological Service, 86, 148-152, 1982.

Schumacher, C. J., Pöhlker, C., Aalto, P., Hiltunen, V., Petäjä, T., Kulmala, M., Pöschl, U., and Huffman, J. A.: Seasonal cycles of fluorescent biological aerosol particles in boreal and semiarid forests of Finland and Colorado, Atmos. Chem. Phys., 13, 11987-12001, doi:10.5194/acp-13-11987-2013, 2013.

Sesartic, A., Lohmann, U., and Storelvmo, T.: Modelling the impact of fungal spore ice nuclei on clouds and precipitation, Environ. Res. Lett., 8, 014029, doi:10.1088/1748-9326/8/1/014029, 2013.

Setlow, B. and Setlow, P.: Levels of Oxidized and Reduced Pyridine Nucleotides in Dormant Spores and During Growth, Sporulation, and Spore Germination of Bacillus megaterium, J. Bacteriol., 129, 857-865, 1977.

Shiraiwa, M., Selzle, K., and Poeschl, U.: Hazardous components and health effects of atmospheric aerosol particles: reactive oxygen species, soot, polycyclic aromatic compounds and allergenic proteins, Free Radical Res., 46, 927-939, doi:10.3109/10715762.2012.663084, 2012.

Sivaprakasam, V., Huston, A. L., Scotto, C., and Eversole, J. D.: Multiple UV wavelength excitation and fluorescence of bioaerosols, Opt. Express, 12, 4457-4466, 2004.

Sivaprakasam, V., Lin, H.-B., Huston, A. L., and Eversole, J. D.: Spectral characterization of biological aerosol particles using two-wavelength excited laser-induced fluorescence and elastic scattering measurements, Opt. Express, 19, 6191-6208, 2011.

Stanley, W. R., Kaye, P. H., Foot, V. E., Barrington, S. J., Gallagher, M., and Gabey, A.: Continuous bioaerosol monitoring in a tropical environment using a UV fluorescence particle spectrometer, Atmos. Sci. Lett., 12, 195-199, doi:10.1002/asl.310, 2011.

Sterling, M., Rogers, C., and Levetin, E.: An evaluation of two methods used for microscopic analysis of airborne fungal spore concentrations from the Burkard Spore Trap, Aerobiologia, 15, 9-18, 1999.

Tanke, H. J., van Oostveldt, P., and van Duijn, P.: A parameter for the distribution of fluorophores in cells derived from measurements of inner filter effect and reabsorption phenomenon, Cytometry, 2, 359-369, doi:10.1002/cyto.990020602, 1982.

Toprak, E. and Schnaiter, M.: Fluorescent biological aerosol particles measured with the Waveband Integrated Bioaerosol Sensor WIBS-4: laboratory tests combined with a one year field study, Atmos. Chem. Phys., 13, 225-243, doi:10.5194/acp-13225-2013, 2013.

Womack, A. M., Bohannan, B. J. M., and Green, J. L.: Biodiversity and biogeography of the atmosphere, Philos. T. R. Soc. B, 365, 3645-3653, doi:10.1098/rstb.2010.0283, 2010.

$\mathrm{Xu}, \mathrm{Z} ., \mathrm{Wu}, \mathrm{Y}$., Shen, F., Chen, Q., Tan, M., and Yao, M.: Bioaerosol Science, Technology, and Engineering: Past, Present, and Future, Aerosol Sci. Tech., 45, 1337-1349, doi:10.1080/02786826.2011.593591, 2011. 